\title{
Antennarius avalonis (Antennariidae, Lophiiformes) in the southeast Pacific
}

\author{
Antennarius avalonis (Antennariidae, Lophiiformes) en el Pacífico suroriental \\ Walter Sielfeld ${ }^{1}$ \\ ${ }^{1}$ Departamento de Ciencias del Mar, Universidad Arturo Prat, Casilla 121, Iquique, Chile. walter.sielfeld@unap.cl

\begin{abstract}
Specimens of Antennarius avalonis captured in the north of Chile are described. The information is compared with the data presented by previous authors. The distribution of the southeast Pacific species and those known from the continental and insular coasts of Chile is compared.
\end{abstract}

Key words: First record, roughjaw frogfish, Chile

\section{INTRODUCTION}

The genus Antennarius Daudin, 1816 is represented in the eastern South Pacific by A. avalonis distributed from southern California to Perú (Hildebrand 1946, Pietsch \& Grobecker 1987, Chirichigno \& Vélez 1998, Chirichigno \& Cornejo 2001), including Galápagos Islands (Acero \& Garzón 1990) and Coco Island (Robertson \& Allen 2002, Mejía-Ladino et al. 2007). A. coccineus (Cuvier, 1831) reported in Costa Rica, Panamá and Chile; and Clipperton, Cocos, San Félix and Galápagos Islands (Smith \& Heemstra 1986, Pietsch \& Grobecker 1987, Acero \& Garzón 1990, Mejía-Ladino et al. 2007), A. randalli Allen, 1970 from Pascua and Fiji Islands and Philipines (Pietsch \& Grobecker 1987), Antennarius sanguineus Gill, 1863 a tropical Pacific species (Schultz 1957, Pietsch \& Grobecker 1987) distributed from the Gulf of California to Callao (Hildebrand 1946), Galápagos and San Félix Islands (Acero \& Garzón 1990, Mejía-Ladino et al. 2007). The present report of $A$. avalonis is the first for the northern continental coast of Chile, extending its distribution range to $20^{\circ} 12^{\prime} \mathrm{S}$.

\section{MATERIAL AND METHODS}

The nomenclature, meristics and morphometry used was based on Dahl (1971), Pietsch (1984), Pietsch \& Grobecker (1987), Robins \& Ray (1986), Acero \& Garzón (1990), Schneider \& Lavenberg (1995), McEachran \& Fechhelm (1998) and Mejía-Ladino et al. (2007). The taxonomic aspects follow to Schultz (1957, 1964), Dahl (1971), Pietsch \& Grobecker (1987), Acero \& Garzón (1990), Cervigón (1991), Böhlke \& Chaplin (1993) and McEachran \& Fechhelm (1998).
Because of the particular morphology of the antennariids, differences in the measuring manner utilized by different authors may be observed. Allen (1970) considers the head length as the distance between the snout tip and the branchial aperture at the level of the base of the pectoral fin. Hildebrand (1946) considers for the same measurement the distance between snout tip and the posterior margin of the opercle and the taxonomic revision of Mejía-Ladino et al. (2007) does not consider the length of head at all.

The measurements as well as the abbreviations of the present specimens follow Mejía-Ladino et al. (2007). The head length follows Allen (1970). For the ray counts of fins the following abbreviations were used: ACD caudal, AD2 dorsal (soft), AP1 pectoral y AA anal fin (Table 2). The rays of the pectoral fins (AP2) were not counted because they are standard $(n=5)$ for the genus, but the bifurcation of the rays represents an important diagnostic character for its species.

The following measurements were taken: TL total length; SL standard length; LC length of the head; LIL length of the illicium; LEC length of the esca; LED2 length of the second dorsal spine; LED3 length of the third dorsal spine; DO eye diameter; DI interorbital distance; LAP1 length of the pectoral fin; LAP2 length of the pelvic fin; LPD predorsal length, from up to the first dorsal spine; LPD2 predorsal length from up to the first soft dorsal ray; LPA preanal length; DRC distance from to anus; APC height of the caudal peduncle; LPC length of the caudal peduncle; LMI length of the lower jaw; LAD length of the 
dorsal fin; LAA length of the anal fin; LR length of the rostrum; LPM length of the premaxillae and; AC1 height of the head and AC2 height of the body.

Antennarius avalonis JORDAN \& STARKS, 1907

Material: Two specimens (264 and $193 \mathrm{~mm}$ TL), collected in a rocky shore sublittoral area at Iquique: northern Chile $\left(20^{\circ} 12^{\prime} \mathrm{S}\right), 15.02 .2000$, respectively deposited under numbers MUAP(P)-0900 and MUAP(P)-0901 in the Zoological Collection of the Departamento de Ciencias del Mar of the Universidad Arturo Prat of Iquique, Chile.

Diagnosis: LEC more or less equal or slightly shorter than LED2. ED2 fused to the head by a reduced membrane that separates two smooth and slighthy concave lateral areas (Robertson \& Allen 2002, Mejía-Ladino et al. 2007). LEC never over 40\% of LIL (Pietsch \& Grobecker 1987, Mejía-Ladino et al. 2007).

Description: Measurements and meristic data of both studied specimens are presented in the Tables 1 and 2, with the following outstanding details: Second dorsal fin rays $12-13$, anal rays 8 , pectoral branched rays 13 . Big head, short, LC 1.9-1.7 in SL, higher than long, LC contained 1.1 in AC1. Caudal peduncle long and slender, LPC 6.1-6.5 in SL and APC 3.8-3.9 in LC. Lower jaw not outstanding 1.8-1.9 in LC. Maxillary wide, its length 2.1-2.5 in LC; Teeth small on both jaws, vomer and palatines in narrow bands. Nasal sacs very conspicuous and small, the anterior ones

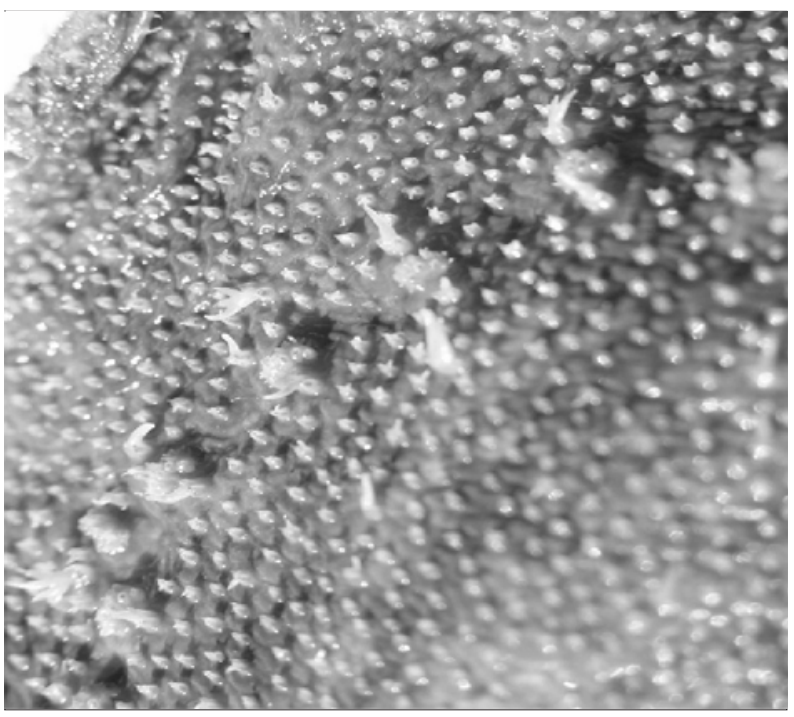

Figure 1. Antennarius avalonis perforated scales of the lateral line (MUAP(P)-0901) / Escamas perforadas de la línea lateral (MUAP(P)-0901) de Antennarius avalonis opened in a short nasal tube. Gill openings short and located under the base of the pectoral fins. The lateral line starts behind and slightly over the eyes and then curves down in direction to the base of the anal fin, at the level of the second dorsal spine. Pores very distinct (Fig. 1). The here studied specimens show 21-23 pores between the eyes and the caudal fin base. The spines of the first dorsal fin are clearly separated between them and from second dorsal fin. The first dorsal spine is very slender, notably shorter than the second (66-76\%), inserted behind the maxillary groove, and with a simple esca composed by a series of short, vertically arranged appendages (Fig. 2), LEC 2.02-2.58 in LIL. The second dorsal spine is shorter and contained 1.67-1.76 in length of the third dorsal spine. The third dorsal spine is connected to the dorsum by a reduced membrane limiting on both sides a slighthy concave and smooth area. LED3 is contained 2.4-2.5 in LC. Margin of the second dorsal fin straight, its longest ray 2.8-3.2 in LC. Anal fin small, its margin concave and its origin at level of the 6th -7th dorsal ray and its length 2.22.8 in LC. Pelvic fins small with length contained 3.5-4.4 in LC. Pectoral fins broad, with branched rays, its length 2.32.4 in LC. Color of body with brown and black blotches, belly and upper side of pectoral fin with numerous diffuse dark blotches, single fins dark, with irregular brown spots, on the basal part of the dorsal fin a black basidorsal blotch surrounded by a narrow orange ring (Pietsch \& Grobecker 1987, Mejía-Ladino et al. 2007). On the sides of the body

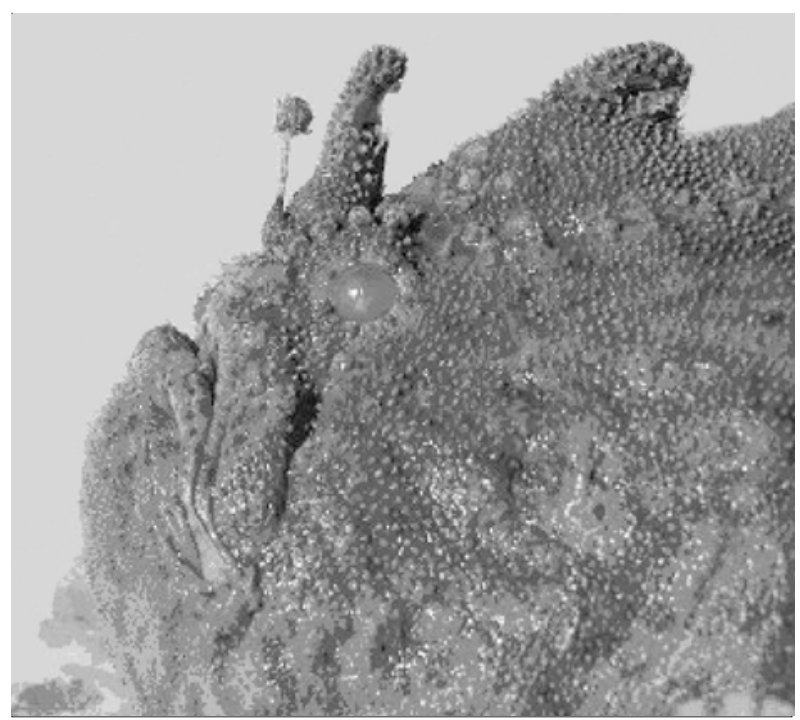

Figure 2. A avalonis esca, illicium and dorsal spines (ED2-ED3) (MUAP(P)-0901) / Esca, illicum y espinas dorsales (ED2-ED3) (MUAP(P)-0901) de A. avalonis 
Table 1. Measurements of the studied $A$. avalonis specimens (MUAP(P)-0900 and MUAP(P)- 0901). SL: Standard length / Medidas de los especímenes de A. avalonis estudiados (MUAP(P)0900 y MUAP(P)-0901). SL: Longitud estándar

\begin{tabular}{|c|c|c|c|c|}
\hline \multirow[t]{2}{*}{ Specimens Measurements } & \multicolumn{2}{|c|}{ MUAP(P) -0900} & \multicolumn{2}{|c|}{ MUAP(P) -0901} \\
\hline & $\mathrm{mm}$ & $\% \mathrm{SL}$ & $\mathrm{mm}$ & $\% \mathrm{SL}$ \\
\hline Standard length & 197.0 & - & 155.0 & - \\
\hline Total length & 281.0 & - & 263.0 & - \\
\hline Height of the head & 120.7 & 61.3 & 96.9 & 62.5 \\
\hline Length of the head & 108.3 & 54.9 & 90.7 & 58.5 \\
\hline Height of the caudal peduncle & 30.2 & 15.3 & 23.8 & 15.4 \\
\hline Length of the caudal peduncle & 31.6 & 16.0 & 25.3 & 16.3 \\
\hline Eye diameter & 10.5 & 5.3 & 7.1 & 4.6 \\
\hline Distance from snout to anus & 138.0 & 70.0 & 109.0 & 70.3 \\
\hline Length of the anal fin & 48.8 & 24.8 & 32.4 & 20.9 \\
\hline Length of the dorsal fin & 38.8 & 19.7 & 28.2 & 18.2 \\
\hline Length of the pectoral fin & 46.6 & 23.7 & 37.2 & 24.0 \\
\hline Length of the pelvic fin & 31.3 & 15.9 & 20.4 & 13.2 \\
\hline Length of the illicium & 13.7 & 7.0 & 10.3 & 6.7 \\
\hline Length of the esca & 5.3 & 2.7 & 5.1 & 3.3 \\
\hline Length of the $1^{\text {st }}$ dorsal spine & 19.0 & 9.6 & 15.4 & 9.9 \\
\hline Length of the $2^{\text {nd }}$ dorsal spine & 25.1 & 12.7 & 23.1 & 14.9 \\
\hline Length of the $3^{\text {rd }}$ dorsal spine & 44.1 & 22.4 & 38.5 & 24.8 \\
\hline Length of the lower jaw & 59.4 & 30.2 & 49.6 & 32.0 \\
\hline Length of the premaxilae & 51.2 & 25.9 & 35.6 & 23.0 \\
\hline Preanal distance & 167.0 & 84.8 & 121.2 & 78.2 \\
\hline Predorsal length up to the $1^{\text {st }}$ spine & 8.4 & 4.3 & 4.2 & 2.7 \\
\hline Predorsal length up to the $1^{\text {st }}$ soft ray & 87.0 & 44.2 & 73.6 & 47.5 \\
\hline Length of the rostrum & 15.0 & 7.6 & 14.1 & 9.1 \\
\hline Body height & 135.8 & 68.9 & 109.2 & 70.5 \\
\hline
\end{tabular}

Table 2. Meristic values of Antennarius avalonis / Valores merísticos de Antennarius avalonis

\begin{tabular}{lccccc}
\hline Reference & ACD & AD2 & Left AP1 & Right AP1 & AA \\
\hline Mejía-Ladino et al. (2007) & $1-3$ & $11-14$ & $11-13$ & $11-13$ & $7-8$ \\
Miller \& Lea (1972) & $12-14$ & 13 & 13 & $8-9$ \\
MUAP(P)-0900 & 13 & 13 & 13 & 8 \\
MUAP(P)-0901 & 12 & 13 & 13 & 8 \\
\hline
\end{tabular}

two pale blotches in both studied specimens, the inferior most located over the pectoral fin base, both in line with the basidorsal blotch (Fig 3). The size of the blotches is lightly bigger than the eye and its border is diffuse.

Comments: The length of the illicium of the present specimens is shorter than the length of the second dorsal spine, and leads to A. pauciradiatus Schultz, 1957 in the species key of Mejía-Ladino et al. (2007), but the counts of the pectoral branched fin rays, the absence of appendices in the ED2 and the pocket for the esca, differentiate them from this species.

The assignment of the present specimens to A. avalonis is based on the anatomy of the esca, the presence of a basidorsal spot, the meristic data and the pelvic branched rays, and the general morphology of the specimens and their dorsal spines. Length differences of the illicium with

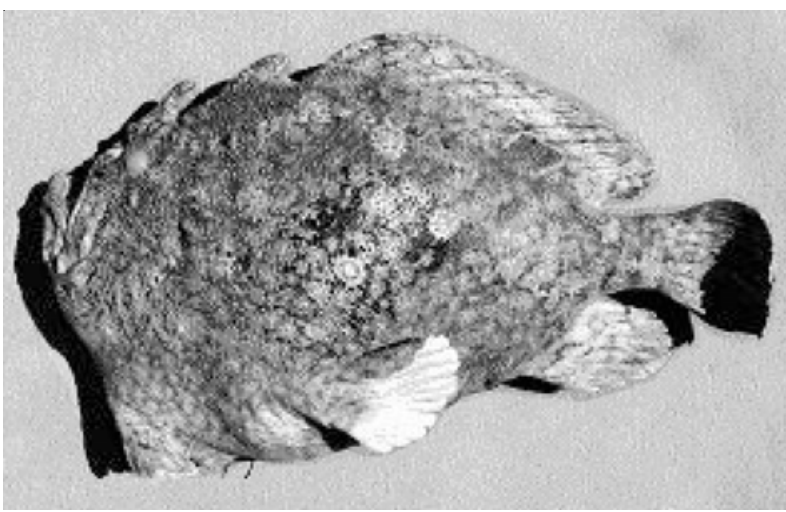

Figure 3. Antennarius avalonis specimen MUAP(P)-0900 / Espécimen de Antennarius avalonis MUAP(P)-0900

values indicated by Mejía-Ladino et al. (2007) may be attributable to the big size of the present specimens, compared with the much smaller individuals of the previous studies (Mejía-Ladino et al. 2007).

Distribution: The genus Antennarius Daudin, 1816 is represented in the eastern Pacific by Antennarius commersoni (Latreille, 1804), A. avalonis Jordan \& Starks, 1907, A. sanguineus Gill, 1863, A. coccineus (Cuvier, 1831) and A. randalli Allen, 1970 (Hildebrand 1946, Acero \& Garzón 1990, Mejía-Ladino et al. 2007). In agreement with Mejía-Ladino et al. (2007), A. avalonis is known for the Eastern Pacific from Isla Santa Catalina in the southern California to Perú (Hildebrand 1946, Pietsch \& Grobecker 1987, Chirichigno \& Vélez 1998, Chirichigno \& Cornejo 2001) including the Galápagos Islands (Acero \& Garzón 1990) and the Coco Island (Robertson \& Allen 2002). The present new record extends the known distribution range in near $8^{\circ}$ to $\mathrm{S}$ latitude $\left(12^{\circ} \mathrm{S}-20^{\circ} 12^{\prime} \mathrm{S}\right)$ from Perú to Iquique Port (Chile), a probable non permanent southern distribution range, fluctuating in relation with faunistic displacements associated to ENSO events. The present specimens were captured during El Niño (ENSO) 1997/98. Including the new specimens, the genus has four species in Chile.

\section{Acknowledgments}

This study was financed through the EU-project CENSOR (Climate Variability and El Niño Southern Oscillation: Impacts for Natural Resources and Management, contract 511071) and the Programa Bicentenario de Ciencia y Tecnología Proyecto CENSOR-RUE02. 


\section{LITERATURE CITED}

Acero A \& J Garzón. 1990. Los antenáridos (Pisces: Antennariidae) de los mares colombianos y aguas adyacentes con énfasis en los del Caribe. Boletín Ecotrópica 21: 5-22.

Allen G. 1970. Two new species of frogfishes (Antennariidae) from Easter Island. Pacific Science 24(4): 517-522.

Böhlke J \& C Chaplin. 1993. Fishes of the Bahamas and adjacent tropical waters, 771 pp. University of Texas Press, Austin.

Cervigón F. 1991. Los peces marinos de Venezuela 1: 1-423. Fundación Científica Los Roques, Caracas.

Chirichigno N \& J Vélez. 1998. Clave para identificar los peces marinos del Perú, 496 pp. Instituto del Mar del Perú, Callao.

Chirichigno A \& C Cornejo. 2001. Catálogo de peces marinos del Perú, 258 pp. Publicación Especial, Instituto del Mar del Perú, Callao.

Dahl G. 1971. Los peces del norte de Colombia, 391 pp. INDERENA, Bogotá.

Hildebrand SF. 1946. A descriptive catalog of the shore fishes of Perú. Bulletin of the United States of National Museum 189: $1-530$.

Hubbs C \& K Lagler. 1958. Fishes of the Great Lakes Region, 213 pp. University Michigan Press, Ann Arbor.

McEachran J \& J Fechhelm. 1998. Fishes of the Gulf of Mexico 1: 1-496. University of Texas Press, Austin.

Mejía-Ladino L,A Acero, L Mejía \& A Polanco. 2007. Revisión taxonómica de la familia Antennariidae para Colombia (Pisces: Lophiiformes), incluyendo un nuevo registro de Antennarius. Boletín de Investigaciones Marinas y Costeras 36: 269-305.
Miller D \& R Lea. 1972. Guide to the coastal marine fishes of California. Fish Bulletin 157: 1-247.

Pietsch T. 1984. The genera of frogfishes (Family Antennariidae). Copeia 1984(1): 27-44.

Pietsch T \& D Grobecker. 1987. Frogfishes of the world: systematic, zoogeography and behavioral ecology, 420 pp. Stanford University Press, Palo Alto.

Robertson D \& G Allen. 2002. Peces costeros del Pacífico oriental tropical: un sistema de información. Instituto de Investigaciones Tropicales, Balboa, Panamá. Versión 1.[CDROM]

Robins C \& G Ray. 1986. A field guide to Atlantic coast fishes of North America, 354 pp. Houghton Mifflin Company, Boston.

Schneider M \& R Lavenberg. 1995. Antennaridae. In: Fischer W, F Krupp, W Schneider, C Sommer, K Carpenter \& V Niem (eds). Guía FAO para la identificación de especies para los fines de la pesca. Pacífico Centro-Oriental 1-3: 854-857. FAO, Roma.

Schultz L. 1957. The frogfishes of the family Antennariidae. Proceedings of the United States of National Museum 107(3383): 47-105.

Schultz L. 1964. Three new species of frogfishes from the Indian and Pacific Oceans with notes on other species (Family Antennariidae). Proceedings of the United States of National Museum 116(3500): 171-182.

Smith M \& P Heemstra. 1986. Smiths' Sea fishes, 1047 pp. Springer-Verlag, Berlín.

Recibido el 20 de julio de 2009 y aceptado el 29 de mayo de 2010 